\title{
The Intended Role of the Senate in Supreme Court Appointments
}

\author{
James E. Gauch $\dagger$
}

He was nominated for the Supreme Court by a popular President. Despite his experience in the federal judiciary, his nomination stirred controversy and national debate. The nominee's political views, which many considered extreme or objectionable, became a focus of the battle over his confirmation. The media attacked the nominee in what his supporters considered a concerted campaign of distortion. Opponents made political attacks, thinly disguised as questions about the nominee's fitness. Finally, the vote in the Senate broke down largely along partisan lines. Thus the Senate rejected John Rutledge for Chief Justice of the Supreme Court in $1795 .^{1}$

The Senate's authority to reject Rutledge, and 28 nominees since, ${ }^{2}$ comes from the Appointments Clause of the Constitution, which states: "[The President] shall nominate, and, by and with the Advice and Consent of the Senate, shall appoint ... Judges of the supreme Court." Although many decried the injection of politics into Robert Bork's nomination and rejection in 1987, political attacks on judicial nominees are nothing new; "nominations to the Supreme Court in the 18th and 19th centuries were expected to be subject to politically motivated attacks."' During the nineteenth century the Senate rejected one out of every four nominees for the Supreme Court, often on strictly partisan grounds. ${ }^{5}$ Of six Supreme Court nominations that President John Tyler sent to the Senate in 1844, only one was approved. The Senate rejected or

$\dagger$ B.A. 1986, Ohio State University; J.D. Candidate 1989, The University of Chicago.

- See notes 126-49 and accompanying text for a detailed discussion of the Senate's rejection of John Rutledge.

${ }^{2}$ See Henry J. Abraham, Justices and Presidents: A Political History of Appointments to the Supreme Court 39 (Oxford, 1985).

3 US Const, Art II, § 2, cl 2.

- Joel B. Grossman and Stephen L. Wasby, The Senate and Supreme Court Nominations: Some Reflections, 1972 Duke L J 557, 560 n 9 (1972).

- Abraham, Justices and Presidents at 39-43 (cited in note 2). See also Joseph P. Harris, The Advice and Consent of the Senate: A Study of the Confirmation of Appointments by the United States Senate 302-03 (Greenwood, 1968). 
postponed the other five, largely because supporters of Henry Clay incorrectly anticipated that he would win the Presidency in 1844. This kind of delaying tactic was common in the nineteenth century. ${ }^{6}$ A lack of qualifications caused few of the rejections. ${ }^{7}$ The influential journalist Horace Greeley once stated that he would oppose a particular choice even if he had all the virtues of Marshall and Story together. ${ }^{8}$ Yet, the Senate has rejected only five nominations in this century, ${ }^{9}$ which helps explain why many considered Bork's rejection illegitimate.

Throughout American history, a number of politicians have argued for a limited Senate role in the judicial appointments process. George Cabot, upon leaving the Senate in 1799, expressed this view:

I have always rejected the idea of non-concurrence with a nomination merely because the nominee was less suitable for office than thousands of others: he must be positively unfit for the office, and the public duty not likely to be performed by him, to justify in my mind the non-concurrence. ${ }^{10}$

In 1970, Richard Nixon argued that it was his constitutional prerogative, as President, to place persons of his own political and ideological persuasion on the Supreme Court. ${ }^{11}$ The views of such people as Cabot and Nixon suggest that the Senate must look only at the basic qualifications, and not at the ideological views of the nominees. Recently, Senator Peter Domenici echoed this view by contending that the Framers rejected appointment by the Senate precisely out of fear "that partisan concerns would overshadow a candidate's merits." 12

Despite these views, the Senate recently rejected Robert Bork, whom even opponents admitted had outstanding academic credentials. While Senator Domenici and others have drawn conclusions from the actions of the Framers in Philadelphia, their conclusions

- Abraham, Justices and Presidents at 40 (cited in note 2).

7 Harris, Advice and Consent at 303 (cited in note 5).

8 John P. Frank, The Appointment of Supreme Court Justices: Prestige, Principles and Politics, 1941 Wis L Rev 172, 178 n 18, citing William N. Brigance, Jeremiah Sullivan Black 113 (Pennsylvania Press, 1934).

- Abraham, Justice and Presidents at 39 (cited in note 2). Robert Bork was the fifth to be rejected in this century.

${ }^{10}$ Harris, Advice and Consent at 44 (cited in note 5) (emphasis in original) .

${ }^{11}$ Letter of Richard M. Nixon to Sen. William Saxbe (March 31, 1970), in 116 Cong Rec 10158 (April 2, 1970).

${ }_{12}$ Senator Peter Domenici, 100th Cong, 1st Sess, in 133 Cong Rec S14914 (Oct 23, 1987). 
have not been based on a comprehensive study of what the Framers and other leaders at the time said about the Advice and Consent Clause and the role of the Senate in the appointment of Supreme Court Justices. ${ }^{13}$ Given the debate on the meaning of the clause and the controversy surrounding the Bork nomination, such a study is needed. Justice Brennan has complained that pleas for adherence to original intent are frequently accompanied by a lack of knowledge of the historical record. ${ }^{14}$ This comment aims to provide that knowledge. ${ }^{15}$

The text of the Appointments Clause is ambiguous. The only express limitation on the Senate's power is that it does not extend to the nomination itself. The grammatical structure of the clause separates the Senate's review from the President's nomination; the phrase "[b]y and with the Advice and Consent of the Senate" modifies "appoint," but is separated from "nominate." This suggests that the power of nomination belongs to the President alone. Even some advocates of a rigorous Senate review have conceded that the power to choose the nominee belongs exclusively to the President. ${ }^{16}$

George Mason, a delegate to the constitutional convention of 1787, reasoned from the text that "[t]he Word 'Advice' [here] clearly relates in the Judgment of the Senate on the Expediency or

13 For an excellent review of the origins of the Appointments Clause which nevertheless draws no conclusions as to the intended role of the Senate, see Theodore Y. Blumoff, Separation of Powers and the Origins of the Appointment Clause, 37 Syracuse L Rev 1037 (1987).

14 William J. Brennan, Jr., Address to the Text and Teaching Symposium, Georgetown $U$ (Oct 12, 1985), reprinted in The Federalist Society, The Great Debate: Interpreting Our Written Constitution 11, 15 (1986).

1s The lack of any transcript from the convention hinders this task. The Journal of the Convention contains little more than the minutes and a record of the votes taken. Max Farrand, ed, 1 The Records of the Federal Convention of 1787 xi-xii (Yale, 2d ed 1937) ("Farrand"). Of the notes taken by delegates, James Madison's are by far the most accurate and complete. Many of the delegates regarded him as a "semi-official reporter" and so provided him with copies of their speeches and motions. 1 Farrand at xvi.

The limitations of these records may always leave the Framers' intent ambiguous. See James H. Huston, The Creation of the Constitution: The Integrity of the Documentary Record, 65 Tex L Rev 1, 2-38 (1986). Nevertheless, this ambiguity no more precludes attempts to discover the intentions behind the Constitution than ambiguity precludes attempts to discern the intent behind wills, contracts, and statutes. See Michael W. McConnell, On Reading the Constitution, 73 Cornell L Rev 359, 361 (1988).

${ }^{16}$ See, for example, Senator Charles McC. Mathias, Jr., Advice and Consent: The Role of the United States Senate in the Judicial Selection Process, 54 U Chi L Rev 200, 202 (1987). But compare Luis Kutner, Advice and Dissent: Due Process of the Senate, 23 DePaul L Rev 658, 666 (1974) (contending that the Constitution contemplates that the President will consult with the Senate before making a nomination). 
Inexpediency of the Measure, or Appointment . . . "17 Similarly, Professor Charles Black has argued that while "consent" could denote a perfunctory task, "Advice" requires a comprehensive review because one could not be a good advisor without considering all the factors. ${ }^{18}$

The problem with this interpretation is that while "Advice" connotes a non-binding interchange, the consent requirement, manifested in the confirmation vote, is binding. If the Senate does not consent, the President and the country are bound by the rejection. Thus a preliminary question is raised as to whether advice and consent are to be taken together, so that "consent" makes the advice binding. If consenting is a separable act from advising, the scope of Senatorial "advice" bears no necessary relation to the binding act of consent. ${ }^{19}$ Strict textual interpretation also ignores different policy considerations that might apply to judicial but not to executive branch appointees. ${ }^{20}$ These problems illustrate the limitations of interpreting "advice and consent" based on the text alone. Therefore, this comment focuses on the historical record in order to shed light on how the text should be interpreted.

Section I analyzes the primary concerns of the Framers at the convention and in the ratification debates. Section II discusses the advice and consent plan in light of these concerns and from that discussion draws conclusions about the original limits on Senatorial power to review Supreme Court nominees. Section III tests those conclusions by examining the Senate's rejection of John Rutledge in 1795, when the Framers and their contemporaries occupied the Senate. Finally, Section IV considers the implications of the Framers' intentions for the modern Court and the appointment process.

The comment concludes that although the debates in the convention focused primarily on the dangers of political corruption and patronage, the Framers were also motivated by concerns for their states' political and economic interests. The Framers consciously divided the power between the Senate and the President in order to protect the interests of all the states and to avoid polit-

17 Letter of George Mason to James Monroe (Jan 30, 1792), in Philip B. Kurland \& Ralph Lerner, eds, 4 The Founders' Constitution 111 (Chicago, 1987).

${ }_{18}$ Charles L. Black, Jr., A Note on Senatorial Consideration of Supreme Court Nominations, 79 Yale L J 657, 658-659 (1970). See also Mathias, 54 U Chi L Rev at 202-203 (cited in note 17) (discussing possibilities for meaningful senatorial advice).

19 E. Edward Bruce, "Advice and Consent" In Selecting Judges Has Its Limitations, 10 Legal Times 12 (Aug 24, 1987).

${ }^{20}$ Richard D. Friedman, Balance Favoring Restraint, 9 Cardozo L Rev 15, 15 (1987). 
ical abuse of the appointment power. Thus, if we are to achieve the ends the Framers desired, the Senate must play an active role in considering not only the basic qualifications of the nominee, but any factors that it deems important. This may occasionally lead the Senate to reject a nominee on what some might consider unfair political grounds, but the Framers fully expected nominations to be played out in the political arena. Their hope was that, on balance, the process would yield good appointments.

\section{The Convention}

\section{A. Background}

Any analysis of the intent behind "advice and consent" is complicated by the divergent appointment schemes considered by the delegates to the Constitutional Convention of $1787 .{ }^{21}$ The Virginia Plan, which provided an early framework for the new constitution, left appointment of judges to the national legislature. ${ }^{22}$ Supporters of this plan soon shifted to James Madison's proposal that the Senate, rather than the entire legislature, should appoint judges. ${ }^{23}$ James Wilson and others strongly opposed both of these systems and instead proposed that the executive appoint judges. ${ }^{24}$

The idea of an appointment power shared between the President and the Senate emerged early in the Convention. On June 5, Alexander Hamilton informally suggested that the Senate have the right of "rejecting or approving" the President's choices. ${ }^{25}$ Nathaniel Gorham proposed the "advice and consent" arrangement on July 18 , but a tied vote among the states defeated the proposal. ${ }^{26}$ Earlier the same day the Convention had rejected appointment by the President alone by a 6-2 vote. ${ }^{27}$ Three days later it rejected a plan that gave the Senate a veto over the President's judicial appointments, and voted to give the Senate exclusive power to appoint judges. ${ }^{28}$

Through the summer, the draft of the Constitution retained

${ }^{21}$ For background on the Constitutional Convention, see Julius Goebel, Jr., 1 History of the Supreme Court of the United States 198-202 (MacMillan, 1971).

221 Farrand at 21 (cited in note 15).

2s Id at 120, 232-33.

${ }^{24}$ Id at 119, 126. William Paterson also proposed appointment by the executive. Id at 244.

25 Id at 128.

262 Farrand at 38, 44. Maryland, Massachusetts, Pennsylvania and Virginia voted yes; Connecticut, Delaware, North Carolina and South Carolina voted no.

${ }^{27}$ Id at 44.

${ }^{28}$ Id at 72,83 . 
appointment by the Senate. In late August, however, the Convention submitted the Appointments Clause, along with other disputed provisions, to the Committee of Eleven. ${ }^{29}$ On September 4, the Appointments Clause that emerged from the Committee of Eleven had been changed again and contained the familiar advice and consent provision. ${ }^{30}$ The convention as a whole approved the clause without dissent on September 7, just ten days before it passed the new Constitution. ${ }^{31}$ George Mason later complained to Thomas Jefferson about "the precipitate, \& intemperate, not to say indecent Manner, in which business was conducted, during the last Week of the Convention ...."32 The atmosphere of the last days of the Convention may very well have influenced the sudden compromise.

\section{B. The Delegates' Concerns}

In debating the various appointment schemes, the delegates focused on three issues: (1) the ability to evaluate the qualifications of potential nominees; (2) corruption and intrigue; and (3) state interests.

\section{Qualifications.}

The delegates to the convention devoted surprisingly little time to discussing the characteristics that they wished Justices of the Supreme Court to have. Instead, most of the debate focused on who-the Senate or the President-would be better able to evaluate candidates. The records of the convention reveal only a requirement of the most basic qualifications for judges. Ellsworth mentioned that they should possess "a systematic and accurate knowledge of the Laws" as well as information on "the law of $\mathrm{Na}$ tions." ${ }^{33}$ Madison noted that " $[t]$ he Legislative talents ... were

28 Id at 473. The committee consisted of one delegate from each state at the convention. Its members were: Abraham Baldwin (Georgia), David Brearley (New Jersey), Pierce Butler (South Carolina), Daniel Carroll (Maryland), John Dickinson (Delaware), Nicholas Gilman (New Hampshire), Rufus King (Massachusetts), James Madison (Virginia), Gouverneur Morris (Pennsylvania), Roger Sherman (Connecticut), Hugh Williamson (North Carolina).

3o Id at 495.

31 Id at 539.

32 John P. Kaminski and Gaspare J. Saladino, eds, 13 The Documentary History of the Ratification of the Constitution 346 (Historical Society of Wis, 1981). See also Goebel, 1 Supreme Court at 244 (cited in note 25) (describing the atmosphere of the final days as "supercharged with discontent").

${ }^{33} 2$ Farrand at 73-74 (cited in note 15). 
very different from those of a Judge ...."34 Possibly believing that such qualifications would be obvious to his fellow delegates and future leaders, Madison did not elaborate on what any of these talents were. For the most part, the delegates spoke only in vague terms about the qualities that candidates for judicial office should possess.

Nevertheless, the debate over which branch of government would be better able to evaluate these vague qualifications sparked a genuine controversy. Discussion focused on whether the Senate or the President would have better information about the quality of candidates. The delegates favoring Senate appointment of judges argued that the Senate would. These arguments appear to have been no more than bald assertions that the Senate would be more familiar with the qualifications of the candidates. ${ }^{35}$ Apparently, the underlying logic was that the President would lack this information because his work would be concentrated in the Capital, while the senators would have access to such information through contacts with their home states. ${ }^{36}$

Those who came to support a mixed appointment power split on this issue. In the first Congress, Madison stated that the primary reason behind senatorial participation in the appointments process was the senators' betier acquaintance with the characters of the candidates. ${ }^{37}$ However, some delegates reasoned that the President, with contacts throughout the country, would have superior access to information..$^{38}$

\section{Intrigue and corruption.}

The most frequently articulated concern in the appointment debates was corruption. Supporters of nearly every plan charged that the other plans would result in political dealing, patronage, favoritism, and intrigue. While these attacks were most frequently directed against plans that gave appointment power to one branch alone, the advice and consent plan also came under attack.

The opponents of Senate appointment argued that a large group such as the Senate would be more susceptible to the pressures of political patronage and favoritism. Nathaniel Gorham, the sponsor of the advice and consent system, forecast that giving the

341 Farrand at 120.

3s 2 Farrand at 41, 43, 81, 82 (Martin, Sherman, Pinckney and Gerry).

so Id at 81 (Ellsworth).

373 Farrand at 357.

${ }^{38}$ Id at 82 (G. Morris). 
appointment power to a body such as the Senate would "give full play to intrigue \& cabal." 38 The charges of "intrigue" appear frequently in Madison's notes. Delegates often expressed their worry about the personal political considerations that could motivate legislators' choices: Madison warned that the legislature might "hide ... selfish motives" in its numbers; Wilson spoke of "intrigue, partiality, and concealment;" and Edmund Randolph feared "personal regard" would govern the body's choices. ${ }^{40}$

To John Adams, who corresponded with the Convention from England, and to Alexander Hamilton, intrigue included favoritism and bargaining for votes. ${ }^{41}$ The fear of intrigue derived in part from the experiences of the Framers in the Articles of Confederation Congress, ${ }^{42}$ as well as their experiences in the states. Gorham pointed to the "wickedness" of cabal under Rhode Island's appointments by the legislature. ${ }^{43}$ James Madison acknowledged that the legislature as a whole could be partial to its members: "The candidate who was present, who had displayed a talent for business in the legislative field, who had perhaps assisted ignorant members in business of their own, or of their Constituents, or used other winning means, would without any of the essential qualifications for an expositor of the laws prevail . . . "44 However, he believed that the Senate, being smaller and more stable and independent, would be above such self-interested partiality. ${ }^{45}$

On the other hand, many delegates argued that the President would be more vulnerable to political pressures than the Senate. They reasoned that it is easier to corrupt one person than many. ${ }^{46}$ Several delegates also argued that giving complete power of appointment to the President would make him too powerful and king-like. ${ }^{47}$ George Mason warned of the improper influence the President could exert over the judiciary if he was involved in

38 Id at 42. See also 1 Farrand at 119, 120 (Wilson, Madison); 2 Farrand at 81, 389 (Randolph, G. Morris).

102 Farrand at 80 (Madison); 1 Farrand at 119 (Wilson); 2 Farrand at 81 (Randolph).

41 Letter of John Adams to Roger Sherman (July 20, 1789), in 4 The Founders' Constitution at 107 (cited in note 17); Federalist 76 (Hamilton) in Benjamin Fletcher Wright, ed, The Federalist 480-81 (Harvard, 1961).

42 Farrand at 539 (G. Morris) (cited in note 15).

43 Id at 42 .

41 Farrand at 232-233.

6s Id at 120, 233. See also, Jack N. Rakove, The Madisonian Moment, 55 U Chi L Rev 473, 482 (1988) (discussing Madison's vision of a Senate free from political pressures).

182 Farrand at 43 (Sherman).

47 Farrand at 119 (Rutledge); 2 Farrand at 81 (Ellsworth). 
appointments. ${ }^{48}$

The shared responsibility notion incorporated in the advice and consent system was not immune from accusations of intrigue and corruption either. Expanding on the prospect of intrigue and corruption raised at the Convention, Adams forecast that Senators would want to get their allies appointed, and the resultant political dealing would lead to "corruption of the grossest kinds." tion, Adams felt that a "check" on the President was troublesome. If the power to reject a nominee was not used, then there would be no reason to have it. It would only open the Senate up to censure from the people for not using it. If, on the other hand, Senators rejected a candidate, they would expose themselves to the resentment of the President and his friends, who would hold most of the offices in government.. ${ }^{50}$ Despite the frequency with which the delegates raised the issue, the fear of intrigue in the nomination process was not completely sincere. During the debate on the method of electing the President, George Mason noted the inconsistency of some of the arguments: "At one moment we are told that the Legislature is entitled to thorough confidence, and to indefinite power. At another, that it will be governed by intrigue \& cabal, and cannot be trusted at all." 11 John Randolph was one delegate who was clearly guilty of such inconsistency during the debates over judicial appointments. On July 18, Randolph, who had strongly supported appointment by the legislature, argued that recording the votes would give the Senate responsibility and contended that the executive would be more vulnerable to intrigue. ${ }^{52}$ Three days later, however, when he shifted his support to the advice and consent proposal, Randolph "laid great stress on the responsibility of the Executive as a security for fit appointments. Appointments by the Legislatures have generally resulted from cabal, from personal regard, or some other consideration than a title derived from proper qualifications." 53 It is unlikely that Randolph suddenly realized that appointment by the legislature or the Senate, which he had

48 2 Farrand at 83. Madison's notes do not indicate what sort of influence concerned Mason.

40 The Founders' Constitution at 107 (cited in note 17). It is important to note that Adams was a vigorous opponent of the advice and consent system. Thus, he would likely exaggerate the dangers of the system in order to discourage its adoption.

so Id. However, even if the Senate were subject to resentment, this may not outweigh the need to check Presidential power.

s1 2 Farrand at 31 (cited in note 15).

B2 Id at 43.

ss Id at 81. 
supported since submitting the Virginia Plan nearly two months before, had problems. His change of heart can be explained, however, if one looks at the state rivalry controversy that pervaded the Convention and the Appointments Clause debates.

\section{State interests.}

Delegates from the smaller states came to Philadelphia wary that the large states might use the convention's proposals to oppress and dominate them. On June 27 and 28, Luther Martin delivered a speech of more than three hours in which he stressed that the federal government must serve the states, rather than govern individuals, and that the three largest states, with the help of only one other, could make themselves "compleat masters of the rest."." The state rivalries arose not so much from state pride as from size and regional interests.

The Great Compromise, which gave all states equal representation in the Senate, brought the issue to a head and threatened to end the convention. On July 16, the convention approved, five states to four, equal representation for each state in the Senate. ${ }^{65}$ This produced a backlash among the large states. Randolph, from Virginia, objected to the compromise because all the powers in the draft Constitution were based on proportional representation in both houses. He therefore "wished the Convention might adjourn [until tomorrow], that the large States might consider the steps proper to be taken in the present solemn crisis of the business, and that the small States might also deliberate on the means of conciliation." Many of the delegates from larger states met the following morning to discuss their course of action. ${ }^{57}$

Ultimately the large states accepted equal representation for each state in the Senate, but even after the apportionment de-

s4 1 Farrand at 437-438, 444-445. Contrast id at 494-495 (Wilson discounting the concerns of small states and arguing for proportional representation).

${ }^{\text {ss }} 2$ Farrand at 13-15 (cited in note 15). Virginia and Pennsylvania were joined by South Carolina and Georgia in opposition; Massachusetts was divided. Equal suffrage was a major portion of the resolution, but other provisions, such as the apportionment of seats in the House, may have affected the voting. Further, delegates from South Carolina and Georgia may have joined the large states in the belief that the southern states would soon be among the most populous. Robert Rutland, et al, eds, 12 The Papers of James Madison 379 (U Va, 1977); 1 Farrand at 604-605. See also Drew P. McCoy, James Madison and the Vision of American Nationality in the Confederation Period: A Regional Perspective, in Richard Beeman, et al, eds, Beyond Confederation 226, 228 (U NC, 1987).

so 2 Farrand at 17-18. Virginia, Massachusetts and Pennsylvania were generally considered "large" states, and the others "small" states. See 1 Farrand at 177, 438.

57 2 Farrand at $19-20$. 
bates, the small states' fears remained. As Calvin Jillson has reported:

The small states continuously eyed the larger states for signs that they were attempting to construct a system that benefited them inordinately, while the large states were under a constant temptation to do precisely that. ${ }^{\mathbf{5 8}}$

These interstate concerns pervaded the debates on the Appointments Clause. It is such concerns, and to a lesser extent fears of corruption, that reveal the intent behind the Advice and Consent Clause.

\section{The Intended Meaning of Advice and Consent}

Against this backdrop of fears of corruption and state rivalry, we can draw several conclusions about how the Framers intended the advice and consent system to operate. The advice and consent plan emerged as a compromise incorporating what were seen as the principal advantages of each of the other major plans: the personal responsibility of appointment by the President and the security of appointment by the Senate. The concern over personal responsibility for bad choices accounts for placing the nomination power in the President's hands alone. The concern over unchecked favoritism by the President accounts for the Senate's participation and suggests that the Senate must at least go beyond basic qualifications to consider the President's motivation for nominating this particular nominee. Lastly, as discussed below, the role of state rivalry suggests that the Framers intended a wide open and largely unrestricted political evaluation of the nominee. This section first examines the part state rivalry played in the acceptance of the advice and consent system, then discusses the theory behind dividing the appointment power between the President and the Senate, and lastly considers how far the Senate's review is to extend.

\section{A. Advice and Consent and State Rivalry}

The Supreme Court has stated that the advice and consent system gave the Senate a role in order to prevent the President from making too many appointments from the larger states. ${ }^{58}$ It based this conclusion on statements to that effect made by Roger

sB Calvin C. Jillson, Constitution Making: Confict and Consensus in the Federal Convention of 1787152 (Agathon, 1988).

so Myers v United States, 272 US 52, 119-20 (1926). 
Sherman and Oliver Ellsworth in the Connecticut ratification debates. ${ }^{60}$ Professor Joseph Harris rejects this state rivalry view as an "afterargument" constructed to defend the Constitution, rather than a major influence at the Convention. He believes that the system eventually adopted was a compromise between delegates that favored and those that feared a strong executive. ${ }^{61}$ While Professor Harris correctly observes that delegates from both large and small states were on both sides of the issue, his conclusion ignores the role state rivalry played in the Convention in general and in the appointments debates in particular. Furthermore, the records of the convention show Madison arguing that the shared appointment power would better balance the interests of large and small states. ${ }^{62}$ Thus, state rivalry could not have been merely an afterthought.

The theory that state interests played a large role in the adoption of the advice and consent plan finds support in the voting patterns on the appointment proposals in the July debates. Because votes at the convention were conducted by state, one can see that the votes did break down along lines between large and small states, even though individual delegates from those states were on both sides of the issue. On July 18, two days after the Great Compromise, the convention soundly rejected appointment by the President alone, with only Massachusetts and Pennsylvania voting in favor of the proposal. ${ }^{63}$ Those states were joined by Virginia and Maryland in supporting Gorham's advice and consent motion, but the motion failed by a tied vote. ${ }^{64}$ By July 21 , the battle lines were more clearly drawn. The convention rejected Madison's proposal of appointment by the President unless vetoed by a majority of the Senate, which was essentially equivalent to advice and consent in terms of smaller state interests; Virginia, Massachusetts and Pennsylvania voted yes, and six smaller states voted no. ${ }^{65}$ Appointment solely by the Senate, in which the smaller states would have relatively more power than in the executive branch, was approved with the three largest states voting no, and the six remaining voting yes. ${ }^{66}$

Explicit evidence of the role that state rivalry and the Great

\footnotetext{
${ }^{60}$ Id, citing 3 Farrand at 99.

${ }^{61}$ Harris, Advice and Consent at 26 (cited in note 5).

${ }^{62} 2$ Farrand at 80-81 (cited in note 15).

${ }^{63}$ Id at 44.

of Id.

Bs Id at $71-72,83$.

${ }^{68}$ Id at 72.
} 
Compromise played in the Appointments Clause debates can also be found in the statements of various Framers. Madison recognized that:

[A]s the [Senate] was very differently constituted when the appointment of the Judges was formerly referred to it, and was now to be composed of equal votes from all the States, the principle of compromise which had prevailed in other instances required in this that [there] shd. be a concurrence of two authorities, in one of which the people, in the other the states, should be represented. ${ }^{67}$

Delaware's Bedford acknowledged the danger that if the appointment power was left to the executive, "[i]t would put it in his power to gain over the larger States, by gratifying them with a preference of their Citizens." ${ }^{88}$ Later, in the Connecticut ratification debates, Oliver Ellsworth noted that the Compromise insured smaller state participation in the appointments process. ${ }^{69}$

A rift between North and South may also have motivated the advice and consent plan. Madison suggested that the reduced Senate participation in the advice and consent plan would prevent the northern states from dominating the South. ${ }^{70}$ This may have been rhetoric aimed at persuading the smaller southern states to break with the other small states and oppose Senate nomination out of fear of domination by the North on slavery issues. Ironically, given the judicial battles over slavery in the 1800 's, a fellow Virginian, Mason, rebuffed Madison's line of reasoning. He could "not see that [the varying interests of North and South] had any connection with the Judiciary department."'11

The voting patterns and the recorded notes from the period thus reinforce the claim that the Great Compromise influenced the adoption of the Advice and Consent Clause. As mentioned, Edmund Randolph is one delegate who probably changed his position based on equal state representation in the Senate. He tentatively stuck to his support of appointment by the Senate right after the Compromise: "It is true that when the appt. of the Judges was vested in the $2 \mathrm{~d}$. branch an equality of votes had not yet been given to it. Yet he had rather leave the appointmt. there than give

\footnotetext{
${ }^{67}$ Id at $80-81$.

is Id at 43.

38 Farrand at 99.

${ }^{70} 2$ Farrand at 81.

${ }^{71}$ Id at 83.
} 
it to the Executive." $"$ Three days later, however, he spoke in favor of Gorham's advice and consent proposal and against Senate appointment. ${ }^{73}$ Such a rapid change of position, by one who favored legislative appointment of judges from the first day of substantive discussions at the Convention, ${ }^{74}$ is difficult to explain except on the basis of the unexpected vote in favor of equal representation for states in the Senate.

Acceptance of the advice and consent provision can also be seen as a logical, strategic compromise that protected all states' interests. Appointment by the Senate would have hurt large states because it would have allowed small states, representing a minority of the people, to dominate the process. Small states had sufficient votes to win equal representation in the Senate, but they still could not risk alienating and driving away the three largest states that between them comprised nearly half of the union's population..$^{75}$ Thus, the smaller states may have felt it imprudent to hold out for Senate appointment.

Still, the power that large states had to elect their favorite sons as Presidents forced the small states to fight for some meaningful Senate participation so that candidates from their states would receive a fair share of appointments. ${ }^{76}$ Further, all the states, interested in protecting their sovereignty, feared leaving appointments solely to the President, who, unlike a senator, was elected only indirectly through the Elecctoral College and thus was less accountable to state legislatures. ${ }^{77}$

\section{B. Operation of Advice and Consent in Theory}

Gouverneur Morris summed up the theory behind the advice and consent system this way: "as the President was to nominate,

${ }^{72} \mathrm{Id}$ at 43.

${ }^{73}$ Id at 81.

741 Farrand at 21.

${ }^{75}$ Using the representation in the First Congress's House of Representatives as an approximation of population, Virginia, Massachusetts, and Pennsylvania had $40-45 \%$ of the national population (26 votes), slightly more than the six states that voted for Senate appointment (25 votes). US Const, Art I, \& 2, cl 3. For the population figures on which the allocation of representatives was based, see 1 Farrand at 572-74. While the numbers do not accurately reflect population because slaves were discounted, they provide a rough gauge of the relative political strengths of the states.

${ }^{76} 3$ Farrand at 99 (letter of Ellsworth and Sherman) and at 348-49 (statement of Davie in the North Carolina convention); Myers $v$ United States, 272 U.S. 52, 119-20 (1926). Martin stated a similar concern when addressing the Maryland General Assembly. See Herbert J. Storing, ed, 2 The Complete Anti-Federalist 31 (Chicago, 1981).

${ }^{73} 3$ Farrand at 357 (Sherman) (cited in note 15). 
there would be responsibility, and as the Senate was to concur, there would be security." 78 These respective features of each branch's participation tell much about their intended roles in the appointment process. First, the nomination power must be left exclusively to the President, or else responsibility will be diluted. Second, the Senate must consider more than simply a nominee's basic, legal qualifications, or its check on the President will be ineffective.

\section{Presidential Responsibility.}

Gorham, in proposing the advice and consent plan, emphasized that because the President alone would choose nominees, he would be responsible for his choice and thus would feel a greater sense of duty, unlike individual senators who could avoid accountability by blaming their colleagues for a poor choice. ${ }^{79}$ Madison made the same point in shifting his support from Senate appointment to a Senate veto plan, which was similar to Gorham's plan. ${ }^{80}$ In The Federalist, Alexander Hamilton later emphasized that better choices would result if the responsibility for a choice rested on one person because a single person would have fewer personal attachments to gratify and the responsibility would "beget a livelier sense of duty and a more exact regard to reputation." "81 Others, including anti-Federalists Jefferson and Mason, agreed that the Senate had no role in the nomination process under the advice and consent plan. ${ }^{82}$ This interpretation is consistent not only with the responsibility rationale, but with the text of the clause, in which "nominate" is set off from "advice and consent."83

Some Framers felt that exclusive presidential nominating power would be insufficient to preserve responsibility. Both John Adams, who was not at the convention but who became a strong critic of the Appointments Clause, and James Wilson complained that "blending" the appointment power between the President and the Senate would lessen the personal responsibility which would bind the President to make good appointments. They reasoned

782 Farrand at 539.

79 Id at $41-43$. See also id at 389 (G. Morris).

so Id at $80-81$.

${ }^{81}$ Federalist 76 (Hamilton) in The Federalist at 480, 481 (cited in note 41).

82 See Letter of Thomas Jefferson to Col. Henry Lee (April 26, 1790), in Paul L. Ford, ed, 5 The Writings of Thomas Jefferson 162 (Knickerbocker, 1895); Letter of George Mason to James Monroe (Jan 30,1792), in 4 The Founders' Constitution at 110, 111 (cited in note 17); 3 Farrand at 162 (Wilson) (cited in note 15).

${ }^{3}$ US Const, Art II, $\S 2$, cl 2. See text accompanying notes 16-20. 
that under the adopted system the Senate's participation would mute the blame for poor appointments. ${ }^{84}$ Hamilton, however, argued persuasively that responsibility would be enhanced through the Senate's participation:

It will readily be comprehended, that a man who had himself the sole disposition of offices, would be governed much more by his private inclinations and interests, than when he was bound to submit the propriety of his choice to the discussion and determination of a different and independent body. . . ${ }^{85}$

Hamilton's language suggests that, in order to make sure that the President lives up to his constitutional responsibility, the Senate must review the propriety of the presidential choice, not just the basic qualifications of the nominee.

\section{A Senatorial Check.}

Some delegates felt that presidential responsibility would prove illusory. ${ }^{86}$ Indeed, relying on personal responsibility alone to protect against poor or politically motivated choices seems somewhat naive and contrary to the colonies' experience with England. While Gorham asserted that the threat of public censure would restrain "honorable minds," the quality of leaders selected, recognized that "enlightened statesmen will not always be at the helm." ${ }^{\text {88 }}$ Thus, the Framers fashioned a system of checks and balances that set ambition against ambition. ${ }^{89}$ As Madison explained, "[a] dependence on the people is, no doubt, the primary control on the government; but experience has taught mankind the necessity of auxiliary precautions." Therefore, the Framers did not expect that responsibility in the executive alone would solve the appointments problems.

The senatorial role provided security against "any flagrant partiality or error." ${ }^{\text {91 }}$ Gorham's analogy to the Massachusetts system of appointments supports the view that he intended his advice and consent plan to prevent abuse of power by the President. When Gorham proposed the system, he observed that his state of

\footnotetext{
84 4 Founders' Constitution at 106, 110 (cited in note 17).

${ }^{86}$ Federalist 76 (Hamilton) in The Federalist at 480, 483 (cited in note 41).

ss 2 Farrand at 43, 539 (Bedford, Gerry) (cited in note 15).

87 Id at 43.

${ }^{88}$ Federalist 10 (Madison) in The Federalist at 129, 132 (cited in note 41).

89 Federalist 51 (Madison) in The Federalist at 355, 356.

so Id.

91 2 Farrand at 80-81 (Madison) (cited in note 15).
} 
Massachusetts had used "advice and consent" successfully. ${ }^{92}$ The Massachusetts system was somewhat different from Gorham's plan; the governor appointed judges "by and with the advice and consent" of a council of nine senators chosen by the legislature. ${ }^{93}$ But according to the Address of the Convention of 1780, the system was designed to prevent the abuse of power by the governor. ${ }^{94}$

The Senate's role as a check on presidential power emerged as a theme during the ratification period. In The Federalist, Hamilton contended that the "right of nomination would produce all the good of that of appointment, and would in great measure avoid its evils." $\mathrm{He}$ reasoned that the Senate's participation would be an "excellent check on the spirit of favoritism in the President . . .."96 Abraham Baldwin, also a signer of the Constitution, took a similar view. ${ }^{97}$ Tench Coxe thought dividing the appointment power would prevent patronage, influence, and judicial dependence on the President. $^{98}$ The importance of a Senatorial check thus accepted, the critical inquiry becomes how far the Senate may go in performing this function.

\section{Extent of the Senate's Review}

Although there are some suggestions in the early history of the national government that the Senate's role was only advisory, upon examination it is clear that the Framers intended the Senate's check to involve a vigorous review of judicial nominees. During the

92 Id at 41 .

9s Mass Const of 1780 , $2 \mathrm{~d}$ pt, ch II, $\S$ I, art IX; id at $2 \mathrm{~d}$ pt, ch II, $\S$ III, art II.

" Oscar and Mary Handlin, eds, The Popular Sources of Political Authority: Documents on the Massachusetts Constitution 438 (Harvard, 1966). Although one author refers to the council as "an advisory body to the governor," Ronald M. Peters, Jr., The Massachusetts Constitution of 1780: A Social Compact 61 (U Mass, 1978), its advice must have bound the governor, or it would not have been able to prevent abuse of power. Nevertheless, Gorham did not elaborate on the kinds of abuse for which the Massachusetts system was designed.

${ }^{23}$ Federalist 77 (Hamilton) in The Federalist at 484, 486 (cited in note 41). Note that because The Federalist was written to persuade the people of New York that the new Constitution should be ratified, their theoretical discussions of checks and balances and separation of powers were frequently elevated above the practical political considerations that largely influenced the delegates to the convention. Blumoff, 37 Syracuse $L$ Rev at 1070 (cited in note 13). See also Geoffrey R. Stone, et al, Constitutional Law 7 (Little Brown, 1986).

${ }^{96}$ Federalist 76 (Hamilton) in The Federalist at 480,483 (cited in note 41 ).

97 1 Annals of Congress 580 (Gales Seaton, 1834).

93 Tench Coxe, "An American Citizen" Essay I, in 13 Documentary History at 247, 250 (cited in note 32). Coxe's works on the Constitution circulated widely, and he corresponded with Madison. John P. Kaminski and Gaspare J. Saladino, eds, 15 The Documentary History of the Ratification of the Constitution 453-54 (State Historical Society of Wis, 1984). 
First Congress, Madison claimed that the Constitution joined the Senate with the President, "merely for the sake of advising, being supposed, from their nature, better acquainted with the character of the candidates than an individual." "99 Fisher Ames, another member of Congress, described the Senate as "merely an advisory body." 100 These statements should not be read as an endorsement of limited senatorial review, however. Madison's statement directly contradicts several speeches he gave at the Constitutional Convention, in which he stated that the Senate would check partiality and error by the President. ${ }^{101}$ Moreover, Madison made his "merely for the state of advising" comment during a debate on removal power for executive officers, not judges. ${ }^{102}$ Ames later qualified his comment; he meant only to say that though the Senate must evaluate a candidate, it cannot nominate one. ${ }^{103}$

A merely advisory role would be inconsistent with the compromise on the Appointments Clause reached in the last days of the convention. Proponents of Senate appointment had the upper hand because their plan won official approval in July by a 6-3 vote. ${ }^{104}$ As discussed previously, there are many ways to explain the compromise. Perhaps the small states became concerned that the three states voting in the negative nearly outnumbered them in population. Or perhaps the initiative on appointments was shifted to the President in exchange for a great small state victory on the election of the President. ${ }^{105}$ Regardless of which motivation prevailed, there is not even a hint that the compromise entailed a drastically curtailed role for the Senate, except with respect to the power to nominate. That opponents of Senate involvement vigorously criticized the arrangement strongly suggests that the Senate still had a meaningful role. ${ }^{106}$

During the ratification debates many leaders spoke of the Sen-

39 Farrand at 357 (cited in note 15).

1001 Annals of Cong at 561 (cited in note 97).

1012 Farrand at $42-43,80$ (cited in note 15 ).

${ }^{102}$ The rationale for using strict senatorial controls to ensure good appointments to an independent, life-tenured branch of the government is less applicable to executive officials who can be removed from office. Furthermore, during the Congressional debates on the removal power, Madison had his own political aim, which was to insure that the President be accorded the constitutional authority to remove officers in the executive branch. Thus, he needed to show that preventing a removal infringes much more on the President's freedom of choice than does rejecting a nomination.

${ }^{103} 1$ Annals of Cong at 565 (cited in note 97).

1042 Farrand at 72.

${ }^{105}$ See Jillson, Constitution Making at 171 (cited in note 58).

${ }^{206}$ See 4 Founders' Constitution at 106-107, 110 (Adams and Wilson) (cited in note 17). 
ate's role in expansive terms. Hamilton stated that "[the President] was bound to submit the propriety of his choice to the discussion and determination of a different and independent body . . . ."107 Thomas Stone expressed a similar view in Congress: "The President only nominates a person for [the Senate's] consideration; they judge upon the propriety of the nomination."108 One author likened the President to no more than a nominating member of the Senate, implying that executive and Senate should use the same criteria to review nominees. ${ }^{109}$ George Mason believed that the Senate could interfere with everything but the nomination, implying that it could consider any factors, except a desire that a particular person be nominated. ${ }^{110} \mathrm{He}$ feared, however, that the Senate would play a largely passive role: "The false complaisance which usually prevails in such cases will prevent a disagreement to the first nominations." 111 On the other hand, the Federal Farmer observed that "the presumption is, that the will of so important a body will not be very easily controulled, and that it will exercise its powers with great address." ${ }^{\text {"12 }}$ Elbridge Gerry, a delegate to the Convention, also believed that the Senate's consent was not "virtually given."113

These arguments alone leave the Senate's role ambiguous. The Senate was meant to look beyond basic qualifications, but the real question is what factors the Framers expected and intended the Senate to consider. Most importantly for the modern day, did the Framers intend the Senate to consider a nominee's ideology and

${ }^{107}$ Federalist 76 (Hamilton) in The Federalist at 480, 483 (cited in note 41). See Black, 79 Yale $L J$ at 662 (cited in note 18) (arguing that Federalists 76 and 77 support Senate consideration of a nominee's views of social justice). But compare William G. Ross, The Functions, Roles, and Duties of the Senate in the Supreme Court Appointment Process, 28 Wm \& Mary L Rev 633, 640 (1987) (Hamilton saw the Senate's role as limited to "checking cronyism"); Kutner, 23 DePaul L Rev at 666 (cited in note 16) (Hamilton did not expect the Senate to have much influence over appointments).

${ }^{103} 1$ Annals of Cong at 587 (cited in note 97).

${ }^{109}$ William Findley ("Hampden"), Pittsburgh Gazette (Feb 16, 1788), in Merrill Jensen, ed, 2 The Documentary History of the Ratification of the Constitution 663, 667 (Historical Society of Wis, 1976).

110 The Founders' Constitution at 111 (cited in note 17).

1112 Farrand at 83 (cited in note 15). See also id at 81 (Ellsworth).

112 Federal Farmer, Letter to the Republican (October 10, 1787), in John P. Kaminski and Gaspare J. Saladino, eds, 14 The Documentary History of the Ratification of the Constitution 30, 33 (Historical Society of Wis, 1983). The works of the Federal Farmer are generally attributed to R.H. Lee, but the accuracy of this is debatable. 14 Documentary History at 15. The Federal Farmer has been called "the ablest and most influential of the anti-federalist pamphleteers." Michael W. McConnell, Federalism: Evaluating the Founders' Design, 54 U Chi L Rev 1484, 1493 (1987).

1131 Annals of Cong at 556 (cited in note 97). 
political affiliation? For the answer to this question, we must look beyond the vague concerns of intrigue and cabal and look into the nature of the state interests that lay behind the Advice and Consent Clause.

During the Convention and the ratification debates the potential importance of ideology went largely unaddressed. At the Convention, only George Mason mentioned the possibility that the President could use the nomination power to exert influence over the judiciary, and he did not specifically address ideological influence. ${ }^{114}$ Indeed, his view of this influence may have been quite narrow, since he did not see the potential for controversy in the courts between North and South. ${ }^{115}$ However, one writer did foresee and approve of the Senate's rejection of a candidate based on ideological grounds. Tench Coxe wrote that the Senate had a check on "unwise or dangerous appointments." Writing as "A Freeman" in 1788 , he gave an example of what might constitute an unwise appointment. He posed a hypothetical in which the Senate could legitimately reject executive branch nominees for ideological reasons:

Let us suppose an expedition on foot, which requires a number of general officers, whom a President might be inclined to appoint from the state to which he belongs, or for which several persons are nominated, that are too partially attached to the federal government, or desirous of lessening the powers of the separate states. The Senate can reject them all, and independently give their reasons to the people and legislatures. That they will often do so, we cannot doubt, when we remember where their private interests, affections and connexions lie, to whom they will owe their seats-to whom they must look for future favors of the same kind. ${ }^{117}$

This scenario is instructive because it takes the view that the Senate can legitimately reject a presidential nominee because of that nominee's political views, even if those political views have

1142 Farrand at 83 (cited in note 15). Madison's notes do not indicate what sort of influence Mason feared.

115 Id.

${ }^{116}$ Coxe, "An American" Essay II, in 15 Documentary History at 165, 176 (emphasis added) (cited in note 98).

${ }^{117}$ Tench Coxe, "A Freeman" Essay III, Pennsylvania Gazette (February 6, 1788), in John P. Kaminski and Gaspare J. Saladino, eds, 16 Documentary History 49, 51 (Historical Society of Wis, 1986) (emphasis in original). Coxe sent a copy of this essay to Madison. 16 Documentary History at 49. 
little to do with the nominee's qualifications. While Coxe's hypothetical does not specifically deal with judicial appointments, the case for rejection is actually stronger for a Supreme Court Justice, whose views are supposed to be independent of the President's. ${ }^{118}$ One's stance on states' rights had little effect on one's qualifications as an expedition officer, but states' rights was a major political issue of the day. Coxe thought that such blatant political bargaining was acceptable.

Of course, Coxe's statements do not represent a consensus. However, when we consider the role state rivalry played in the appointments debates, we see that by including the Senate at all, the Framers tacitly endorsed ideological considerations. Equal state representation meant that any inclusion of the Senate would necessarily involve accommodating different views on states' rights, and different views on states' rights represented political differences. The statements of delegates from the small states indicate that they were concerned that appointees would only come from the large states. Some might argue this concern was based only on a desire for geographic diversity, ${ }^{119}$ but more lay behind small states' motives than an interest in getting their fair share of appointments. Small states feared domination by the large states.

The conflict between large and small states is analogous to modern disputes between political parties. At the time, there were no national parties. Economic and social interests broke down largely along state and regional lines. ${ }^{120}$ Slavery provides one example. The southern states were deeply committed to preserving slavery, while there was strong sentiment in the North for its restriction or abolition. ${ }^{121}$ However, the issue was negotiable:

"[Martin] found the eastern States, notwithstanding their aversion to slavery were very willing to indulge the southern States, at least with a temporary liberty to prosecute the slave-trade, provided the southern States would, in turn, grat-

118 See Black, 79 Yale L J at 660 (cited in note 18).

119 Sherman suggested that appointments ought to be "diffused," thus possibly implying that geographical diversity was good for its own sake. 2 Farrand at 41 (cited in note 15); see also id at 42 (Mason). George Washington based his nomination of James Iredell to the Supreme Court in part on the fact that "he is of a State of some importance in the Union that has given no character to a federal office." Abraham, Justices and Presidents at 79 (cited in note 2).

${ }^{120}$ See McCoy, James Madison, in Beyond Confederation at 229, 239-40 (cited in note 55); Calvin C. Jillson, Constitution Making at 140-63 (cited in note 58).

${ }^{121}$ Jillson, Constitution Making at 129, 140-41 (cited in note 58). 
ify them, by laying no restriction on navigation acts. . .."122

Moreover, there was a division among the southern states on the issue of the importation of slaves, Maryland and Virginia, each of which had a surplus of slaves, split from South Carolina and Georgia, which depended on continued imports. ${ }^{123}$

The slavery dispute shows that states with similar interests functioned much like political parties. Different states organized and voted in accordance with their collective interests and there was bargaining and alignment among and between interest groups. In the convention, the large states and the small states each tried to work together as a group. After the Great Compromise, representatives of the large states met to plot strategy. ${ }^{124}$ Similarly, near the end of the convention, Martin reports that members from the small states began meeting in evening caucuses. ${ }^{125}$

Thus, the significant evidence that the Framers intended the Senate to play more than an advisory role, the recorded beliefs of some that a legislative rejection for purely political reasons was acceptable, and the extent to which any Senatorial participation implicitly acknowledged that it was important to include different political viewpoints in the process, all argue in favor of a Senatorial review power that includes evaluating a nominee's politics.

\section{Testing the Hypothesis: RUTLedge IN 1795}

The political divisions at the Constitutional Convention foreshadowed the party disputes that resulted in the defeat of former Supreme Court Justice John Rutledge for nomination to Chief Justice in 1795 . The Rutledge nomination provides a particularly important opportunity to test the present interpretation of senatorial review because six members of the Senate at that time had been delegates to the convention. ${ }^{126}$

\section{A. Background}

The Jay Treaty, ratified in the summer of 1795 , was negotiated with Britain to minimize and obtain compensation for British

${ }^{122} 3$ Farrand at 210-11, quoted in Jillson, Constitution Making at 146 (emphasis in original).

${ }^{123}$ Jillson, Constitution Making at 141, 144-145.

124 2 Farrand at 19-20 (cited in note 15).

1253 Farrand at 282.

${ }^{128}$ The former delegates were Pierce Butler, Oliver Ellsworth, Rufus King, John Langdon, Alexander Martin, and Caleb Strong. See Biographical Directory of the American Congress 1774-1971, 92nd Cong, 1st Sess 51-52 (GPO, 1971). 
interference with American shipping. ${ }^{127}$ The Republicans criticized the concessions made by the United States, including a tacit admission of Britain's right to confiscate property aboard American ships, because they viewed the United States as strong enough to have exacted more demands from Britain. ${ }^{28}$ The Federalists, however, attached great importance to the treaty because they feared that the Republican position would bring about a war with Britain that would end American independence. ${ }^{129}$

The treaty was very unpopular throughout the nation. The Federalists kept the terms of the treaty secret during the Senate's deliberations and tried to keep them secret even after the treaty was ratified by a vote of $20-10 .{ }^{130}$ When the terms of the treaty were leaked to the public, "few people had even one word of defense for the instrument."

In a speech in Charleston, John Rutledge joined others who had publicly attacked the treaty. ${ }^{132}$ His speech came within days of Rutledge's receipt of a recess appointment for Chief Justice of the Supreme Court. ${ }^{133}$ Because Washington's followers regarded support of the treaty as "the touchstone of true Federalism," they opposed the nomination despite Washington's support. ${ }^{134}$

\section{B. Rejection}

The Federalists therefore set out to block Rutledge's confirmation in the Senate. Rutledge had served on the Supreme Court from 1789 to 1791, before resigning to become Chief Justice of the South Carolina Supreme Court, so his qualifications were above question. Still, the Senate rejected Rutledge by a vote of $14-10 .^{135}$ The vote broke along party lines; only three Federalists voted to

${ }^{127}$ Jerald A. Combs, The Jay Treaty: Political Battleground of the Founding Fathers 132-134, 151-153 (U Cal, 1970).

128 Id at $130,153$.

129 Id at $130-132$.

130 Id at $161-162$.

131 Id at 162.

132 Richard Barry, Mr. Rutledge of South Carolina 355-356 (Duell Sloan, 1942).

153 See Charles Warren, 1 The Supreme Court in United States History 127-128 (Little Brown, 1924) (letter of Rutledge to Washington soliciting appointment); Barry, Mr. Rutledge at 353 (cited in note 132). The vacancy resulted from John Jay's resignation.

${ }^{134}$ Warren, I Supreme Court at 129 (cited in note 133).

195 Barry, Mr. Rutledge at 357-358 (cited in note 141). Barry erroneously states that Luther Martin, George Mason, and George Read voted for Rutledge's confirmation. None of the three served in the Senate. The confusion is probably due to the presence of Alexander Martin, Stevens T. Mason and Jacob Read. See Biographical Directory at 51-52 (cited in note 126). 
confirm Rutledge, while thirteen Federalists and only one antiFederalist voted to reject him. ${ }^{\mathbf{1 3 6}}$

Hamilton, who had led the support of the Jay Treaty while serving as Secretary of the Treasury, led the opposition to Rutledge. ${ }^{137}$ The northern Federalist newspapers also came out strongly against the nomination, and caused further opposition to Rutledge by publishing what Charles Warren described as "false and exaggerated reports."138 Because of the unpopularity of the Jay Treaty, Rutledge's opponents were wary of openly attacking his views on the treaty. Instead, they charged that Rutledge's mental abilities had deteriorated. The claim of mental unsoundness was based on two letters from bystanders who had heard Rutledge's treaty speech and suggested that he sounded like a "crazy man," and on the adjournment of a recent session of the South Carolina court due to Rutledge's illness. ${ }^{139}$

Analysis reveals the fabricated nature of the mental unsoundness claim. First, it is doubtful that Rutledge would have met Washington's "stiff criteria" for service on the Court had he been insane. ${ }^{140}$ Second, Rutledge's subsequent election to the South Carolina assembly suggests that the voters trusted his competence. ${ }^{141}$ Third, Rutledge's performance as acting Chief Justice for five months preceding his rejection evidenced no mental unsoundness. Finally, statements at the time strongly suggest that claims of "insanity" were really based on Rutledge's treaty stand. For example, Secretary of State Edmund Randolph wrote to President Washington that: "The conduct of the intended Chief Justice is so extraordinary that Mr. Wolcott and Col. Pickering conceive it to be a proof of the imputation of insanity."142

Some contemporaries supported the Senate's rejection not because they thought Rutledge insane but because they considered

136 William F. Swindler, The Politics of "Advice and Consent", 56 ABA J 533, 535 (1970).

${ }^{137}$ Barry, Mr. Rutledge at 355,357 (cited in note 132).

138 Warren, 1 Supreme Court at 132 (cited in note 133). See also Abraham, Presidents and Justices at 41 (cited in note 2); Harris, Advice and Consent at 43 (cited in note 5).

${ }_{139}$ Barry, Mr Rutledge at 357-58 (cited in note 132). The Senate did not request or receive any medical reports.

140 See Abraham, Justices and Presidents at 41 (cited in note 2). Washington adhered strictly to six criteria: "(1) support and advocacy of the Constitution; (2) distinguished service in the Revolution; (3) active participation in the political life of state or nation; (4) prior judicial experience in lower tribunals; (5) either a "favorable reputation with his fellows' or personal ties with Washington himself; (6) geographical 'suitability.' "Id at 71-72.

${ }^{141}$ Barry, Mr. Rutledge at 360-61 (cited in note 132).

${ }^{142}$ Quoted in Warren, 1 Supreme Court at 130 (emphasis added) (cited in note 133). 
his speech on the treaty hasty or imprudent, and thus not befitting a Chief Justice of the United States. ${ }^{143}$ Hamilton encouraged this view:

What are we to think of the state of the mind which could produce such extravagant a folly? Would a prudent people have been willing to have entrusted a negotiation which involved their peace to the author of it? ${ }^{144}$

Chauncey Goodrich attributed Washington's decision to nominate Rutledge to "want of information of his hostility to the Government."145 However, that supporters of the treaty generally opposed Rutledge, and opponents of it supported him, indicates that the content of the speech more likely motivated the rejection. Thomas Jefferson, who had led the opposition to the treaty, ${ }^{146}$ saw through this duplicity: "The rejection of Mr. Rutledge by the Senate is a bold thing, because they cannot pretend any objection to him but his disapprobation of the treaty."147

\section{Legitimacy of the Rejection}

The Senate rejected Rutledge primarily because of his opposition to the Jay Treaty, but this in itself does not indicate whether the Framers considered such a rejection legitimate. Two pieces of historical evidence suggest that the Framers may have considered Rutledge's rejection illegitimate. First, there is Jefferson's statement that the rejection based on politics was a "bold thing." Second, the Federalists did not openly attack Rutledge's position on the treaty but rather couched their opposition in the neutral terms of mental competence. Upon closer examination, however, this evidence becomes equivocal.

Significantly, Jefferson did not charge that the action violated the Senate's constitutional role. He may have thought the rejection "bold" not because of its unconstitutionality but because of the widespread unpopularity of the treaty, which could have led to a

143 Id at 137.

14 Harold C. Syrett, ed, 19 The Papers of Alexander Hamilton 91 (Columbia, 1973).

145 Quoted in Warren, 1 Supreme Court at 131-32 (cited in note 133).

14 Barry, Mr. Rutledge at 355 (cited in note 132).

147 Letter of Thomas Jefferson to William B. Giles (Dec 31, 1795), in Paul L. Ford, ed, 7 The Writings of Thomas Jefferson 41, 44 (Knickerbocker, 1896). Jefferson's position finds widespread support among scholars. See, for example, Harris, Advice and Consent at 43 (cited in note 5); Harold C. Syrett, ed, 18 The Papers of Alexander Hamilton 510-11, n 3 (Columbia, 1973); Warren, I Supreme Court at 137-39 (cited in note 133). 
backlash against the Senate. ${ }^{148}$ Rutledge's opponents most likely hid the true grounds of their opposition not because those grounds were illegitimate but because they were very unpopular. They therefore concealed their true reasons for opposing Rutledge, just as they tried, even after they had won ratification of the treaty, to keep its terms secret. ${ }^{149}$ Both sides apparently accepted the constitutionality of the Senate's action, despite the fact that the Senate's objections were not based on the state interest and favoritism concerns that were voiced at the convention.

\section{Modern Implications of the Appointment Debate}

The Framers anticipated that Supreme Court appointments be subject to political scrutiny. The articulated concerns about patronage and corruption and the need to include different ideological perspectives in the process are still valid today. However, modern critics of the system often suggest discounting the Framers' intentions because: (1) the rise of parties has made the system more political than the Framers expected or desired; (2) the politics of the process will obscure the merits of the nominee; and (3) the greatly increased power of the modern Court makes public political battles over nominations less desirable. ${ }^{150}$ These arguments are suspect.

\section{A. Political Parties}

Many modern critics contend that the Framers were blind to the impending rise in power of partisan political parties in American politics. ${ }^{161}$ One writer asserts that "[d]elegates simply assumed, perhaps a mite naively, albeit quite understandably, that those selected as federal jurists would be chosen on the basis of merit. Period."162 With little analysis, these critics claim that only John Adams foresaw that the rise of political parties would cause partisan considerations, rather than the fitness of nominees, to control nominations. ${ }^{153}$ While it is true that organized parties were

${ }^{148}$ See Combs, Jay Treaty at $152-53$ (cited in note 127).

148 Id at 161-162.

${ }^{160}$ See Abraham, Justices and Presidents at 26 (cited in note 2); Grossman and Wasby, 1972 Duke L J at 561-562 (cited in note 4); Harris, Advice and Consent at 28 (cited in note 5); Robert B. McKay, Selection of United States Supreme Court Justices, 9 Kan L Rev 109,129 (1960).

151 Id.

162 Abraham, Justices and Presidents at 26 (cited in note 2).

${ }^{16 s}$ Harris, Advice and Consent at 34 (cited in note 5). 
still several years away in 1787 , the partisan element that parties inject into the process was familiar to the Framers. The Framers were well aware of the dangers of factional politics, as is illustrated by the system of checks and balances they put in place, their knowledge of factional conflict in other nations, and their debates in the Convention over intrigue and patronage. ${ }^{154}$ The conflicts in the Convention between large states and small ones, and between nationalists and anti-Federalists, provide examples of alliances that, while less permanent than modern political parties, had a similar and powerful "politicizing" effect on the process. ${ }^{155}$

Madison anticipated religious and economic conflicts that were every bit as divisive as abortion and affirmative action are today..$^{186}$ The crucial difference between the Framers' conception of faction, as illustrated by Madison, and the modern party system is that Madison saw much greater differences and much more potential for serious conflict between factions. ${ }^{157}$ The historical record at that time was replete with factional conflicts leading nations into bitter civil wars. ${ }^{188}$ The relatively minor ideological differences that characterize modern parties would seem to obstruct the process much less than would the factions for which the system was designed. The Framers would have been lacking in foresight indeed if the system of restraints designed to handle these greater pressures were rendered obsolete when lesser pressures came from formal parties.

\section{B. Politics vs. Merit}

During the ratification debates, John Adams charged that "[f]action and Distraction are the sure and certain Consequence of giving to a Senate a Vote in the distribution of offices." "159 Hamilton, expressing a similar concern, worried that if appointments were left to the Senate, political dealing would obscure the merits of the candidate. ${ }^{160}$ Some make this same argument against a vig-

154 See Benjamin F. Wright, Editor's Introduction, in The Federalist 1, 32-41 (cited in note 41).

${ }^{155}$ Consider, for example, that in the context of the Great Compromise, the large and small states operated with more or less success as clearly defined coalitions. 2 Farrand at 17-20 (cited in note 15).

${ }^{158}$ Wright, Editor's Introduction, in The Federalist at 39 (cited in note 41).

157 Id at 41.

${ }^{158}$ Id.

150 Letter of John Adams to Thomas Jefferson (December 6, 1787), in 14 Documentary History at 473 (cited in note 112).

${ }^{180}$ Federalist 76 (Hamilton) in The Federalist at $480-82$ (cited in note 41 ). 
orous Senate review today. However, these critics fail to note the significance of the shared appointment power and fail to see that limiting Senate review to basic qualifications would not cleanse the process of partisan politics. As Hamilton observed in regard to removal of judges for inability: "An attempt to fix the boundary between the regions of ability and inability, would much oftener give scope to personal and party attachments and enmities than advance the interests of justice or the public good."161

Rather, Hamilton relied on a separation of powers and official accountability in order to avoid excessive political strife. He felt that the fact that the Senate could not choose candidates, and therefore could not assure that subsequent candidates would be more to their liking, prevented the Senate from rejecting a nominee except for good reason. ${ }^{162} \mathrm{He}$ also expected the public to censure the Senate if it rejected a good nominee, thus further discouraging the Senate from rejecting a nominee on partisan grounds. ${ }^{163}$

If Hamilton was right and it is impossible to filter out politics from the review process, then it is certainly better not to force such considerations into the back rooms, or not to couch them in questions of qualifications. If political dealing is inevitable, we should recognize it as such or we will only further obscure the real issues. To the extent that the actual reasons for the Senate rejecting a nominee are obscured, the Framers' desire that people act as the ultimate check is minimized. ${ }^{164}$

\section{Power of the Supreme Court}

Finally, some may charge that the Framers' intent regarding judicial appointments is less useful today because of the greatly increased power of the Supreme Court. However, the Court's relative power makes it more, not less, important that there be an effective check against influence over the judiciary. A more powerful Court means that the stakes of an appointment are higher, so the dangers attendant upon corruption and influence-peddling are even greater.

More importantly, an effective check is needed because the political interests that the Framers sought to recognize play a more direct role in the work of the Supreme Court. While in 1787 some

${ }^{181}$ Federalist 79 (Hamilton) in The Federalist at 497, 498.

${ }^{162}$ Federalist 76 (Hamilton) in The Federalist at 480, 482-83.

163 Federalist 77 (Hamilton) in The Federalist at 484, 486.

104 Tench Coxe, "A Freeman" Essay III, in 16 Documentary History at 49, 51 (cited in note 117). 
delegates failed to see a connection between the Court and important political issues, ${ }^{185}$ today the relationship is undeniable. Given the effect that modern Supreme Court appointments can have on the Constitution itself, the Senate's check on presidential nominations is more valuable than ever. As Senator Edward Kennedy noted: "On occasion, the appointment of a Justice has been the equivalent of a constitutional amendment."168

A rigorous Senate review of nominees to the Supreme Court does not upset the traditional constitutional balance and separation of powers; it strengthens it. The division of the appointment power between the President and the Senate provides precautions against abuse of power by either, and thereby protects the independence of the Supreme Court. If either branch plays a submissive role, the constitutional balance will be threatened.

\section{Conclusion}

As the Framers debated which branch of government could best evaluate the qualifications of potential judges, they designed a system that would minimize corruption and political dealing, while at the same time take account of legitimate and inevitable political interests. The specific ideological concerns have changed with time, but the nature of the conflict has not. The rejection of John Rutledge for the Supreme Court in 1795 supports the view that politically motivated votes are legitimate, if not desirable, under our system of divided appointment power. The Framers realized that politics would enter into the process, just as it had in the adoption of the system during the summer of 1787 . They realized that any criteria they set out for judges could be manipulated by opposing political forces. Therefore, they devised a system that set "ambition against ambition," believing that corruption would be minimized, political forces would balance each other out and worthy candidates would be approved.

\footnotetext{
${ }^{165}$ See, for example, 2 Farrand at 83 (cited in note 15) (Mason denied any connection between the courts and the conflict between North and South).

106 Symposium on Advice and Consent on Supreme Court Nominations, Subcommittee on Separation of Powers, Senate Judiciary Committee, 94th Cong, 2d Sess 2 (1976) (introductory statement of Senator Edward M. Kennedy).
} 


$$
\text { - }
$$

$$
\text { , }
$$

